\title{
ВЗАЕМ03В'Я3ОК СИСТЕМНОГО ЗАПАЛЕННЯ ТА ТИПУ ІНСУЛІНЕМІЇ У ХВОРИХ НА АРТЕРІАЛЬНУ ГІПЕРТЕНЗІЮ 3 МЕТАБОЛІЧНИМ СИНДРОМОМ
}

О.І. Кочержат, М.А. Оринчак, Н.Г. Вірстюк, І.І. Вакалюк, М.М. Василечко, О.Р. Лучко, О.C. Човганюк, I.О. Гаман

Івано-Франківський національний медичний університет, м. Івано-Франківськ

Резюме. Останнім часом науковці звертають особливу увагу на роль імунного запалення в розвитку серцево-судинної патології. Проведено чимало досліджень, у яких виявлено тісний взаємозв'язок між маркерами системного запалення та ризиком виникнення серцево-судинної патології.

Мета роботи — оцінити активність та кореляційний зв'язок маркерів інсулінорезистентності (IP) за рівнем $\beta_{2}$-інсулінових рецепторів, адипоцитокінів, фрактора некрозу пухлин альфа (ФНП- $\alpha$ ) у хворих на артеріальну гіпертензію (АГ) з метаболічним синдромом (MC) залежно від типу інсулінемії.

Матеріал і методи. Обстежено 139 хворих на АГ із МС. Залежно від рівня ендогенного інсуліну (ЕІ) у крові натще хворих розподілено на дві групи: 1-ша група — 59 хворих із нормальним рівнем ЕІ в крові; 2-га група - 80 хворих зі спонтанною гіперінсулінемією (ГІ). Контрольна група - 20 практично здорових осіб.

Результати та обговорення. У всіх обстежених хворих виявили достовірне підвищення рівня $\beta_{2}$-рецепторів інсуліну. У хворих із нормальним рівнем ЕІ в крові та зі спонтанною ГІ рівень $\beta_{2}$-інсулінових рецепторів у 3,4 та 5 разів $(p<0,05)$ відповідно достовірно перевищував показник у здорових осіб. У хворих зі спонтанною ГІ рівень $\beta_{2}$-інсулінових рецепторів виявився в 1,5 раза вищим, ніж у хворих 1-ї групи $\left(\mathrm{p}_{1}<0,05\right)$.

У всіх хворих на АГ із МС відмічено гіперлептинемію та гіпоадипонектинемію. У пацієнтів обох груп рівень лептину в 3,8 та 4,8 раза відповідно перевищував показник здорових осіб $(p<0,05)$. У хворих зі спонтанною ГІ рівень лептину був в 1,3 раза вищим порівняно 3 хворими з нормальним ЕІ в крові $\left(p_{1}<0,05\right)$. У хворих 1-ї та 2-ї груп рівень адипонектину виявився зниженим на 14,75 та 38,0\% відповідно порівняно зі здоровими особами $(p<0,05)$. У хворих $2-і ̈$ групи - на $14,42 \%$ порівняно 3 показником хворих $1-і ̈$ групи $\left(\mathrm{p}_{1}<0,05\right)$.
УДК: 616-002+577.175.1+616.12-

$008.331 .1+616-056.52$

DOI: 10.31793/2709-7404.2021.2-2.50

(c) О.І. Кочержат, М.А. Оринчак,

Н.Г. Вірстюк, І.І. Вакалюк,

М.М. Василечко, О.Р. Лучко,

О.С. Човганюк, І.О. Гаман

Надійшла до редакції 03.06.2021

Адреса для листування (Correspondence): Івано-Франківський національний медичний університет, вул. Галицька, 2, м. Івано-Франківськ, 76018, Україна. E-mail: zdovado@ukr.net 
Рівень ФНП- $\alpha$ був достовірно підвищеним у всіх обстежених хворих. Так, у пацієнтів 1-ї групи цей показник на 13,0\% перевищив рівень у контролі $(p<0,05)$. У хворих 2-ї групи показник ФНП- $\alpha$ на 34,6\% перевищив рівень контролю $(p<0,05)$ та у 2,6 раза виявився підвищеним порівняно 3 хворими 3 нормальним рівнем El в крові $\left(p_{1}<0,05\right)$. Аналіз результатів дослідження маркерів субклінічного ураження органів-мішеней довів наявність прямого кореляційного зв'язку між рівнем ЕІ в крові натще та рівнями $\beta_{2}$-рецепторів інсуліну, лептину та ФНП- $\alpha$; зворотного кореляційного зв'язку між рівнем El та рівнем адипонектину $(r=-0,5845, p=0,0001)$.

Висновки. Особливостями АГ та МС є важкість перебігу та фрормування IP зі спонтанною ГІ, що характеризується зростанням рівнів $\beta_{2}$-рецепторів інсуліну, лептину, ФНП- $\alpha$ та гіпоадипонектинемією.

Ключові слова: артеріальна гіпертензія, метаболічний синдром, інсулінорезистентність, гіперінсулінемія.

\title{
Relationship between systemic inflammation and type of insulinemia in patients with hypertension and metabolic syndrome
}

\author{
O.I. Kocherzhat, M.A. Orynchak, N.G. Virstiuk, I.I. Vakalyuk, M.M. Vasylechko, O.R. Luchko, \\ O.S. Chovganiuk, I.O. Haman \\ Ivano-Frankivsk National Medical University
}

\begin{abstract}
Recently, scientists have paid special attention to the role of immune inflammation in the development of cardiovascular pathology. Many studies have shown a close relationship between markers of systemic inflammation and the risk of cardiovascular disease.

Purpose: to evaluate the activity and correlation of insulin resistance (IR) markers by the level of $\beta_{2}$-insulin receptors, adipocytokines, tumor necrosis factor alpha (TNF- $\alpha$ ) in patients with arterial hypertension (AH) with metabolic syndrome (MS) depending on insulin levels. Material and methods. Were examined 139 patients with hypertension and with MS. Depending on the fasting endogenous insulin (EI) level in the blood of the patients is divided into two groups: group $1-59$ patients with normal El levels in the blood; group $2-80$ patients with spontaneous hyperinsulinemia $(\mathrm{HI})$. Control group -20 healthy people.

Results. All examined patients showed a significant increasing of insulin $\beta_{2}$-receptors level. In patients with normal El levels in the blood and with spontaneous $\mathrm{HI}$ the level of $\beta_{2}$-insulin receptors was 3.4 and 5 times $(p<0.05)$, respectively, significantly higher than in healthy individuals. In patients with spontaneous $\mathrm{HI}$ was 1.5 times higher than in patients of group $1\left(p_{1}<0,05\right)$.

Hyperleptinemia and hypoadiponectinemia were noted in all patients with hypertension with MS. In patients of both groups, leptin levels were higher at 3.8 and 4.8 times than in healthy individuals $(\mathrm{p}<0.05)$. In patients with spontaneous $\mathrm{HI}-1.3$ times higher than in patients with normal El levels in the blood $\left(p_{1}<0,05\right)$. In patients of groups 1 and 2 , the level of adiponectin was reduced by $14.75 \%$ and $38.0 \%$, respectively, compared with healthy people $(p<0.05)$. In patients of group 2 - by $14.42 \%$ compared with patients in group $1\left(p_{1}<0.05\right)$. The level of TNF- $\alpha$ was significantly elevated in all examined patients. Thus, in patients of group 1 this index was exceeded the level in the control by $13.0 \%(p<0.05)$. In patients of group 2, the TNF- $\alpha$ index was exceeded the control level by $34.6 \%(p<0.05)$ and was higher by 2.6 times than in patients with normal blood El levels $\left(p_{1}<0.05\right)$.

The results analysis of the study of subclinical damage markers to target organs demonstrated the presence of a direct correlation between the fasting El level in the blood and the levels of $\beta_{2}$-receptors of insulin, leptin and TNF- $\alpha$; inverse correlation between El level and adiponectin level $(r=-0.5845, p=0.0001)$.

Conclusions. Features of hypertension and MS are the severity of the course and formation of IR with spontaneous $\mathrm{HI}$, characterized by increased levels of $\beta_{2}$-receptors of insulin, leptin, TNF- $\alpha$ and hypoadiponectinemia.
\end{abstract}

Keywords: arterial hypertension, metabolic syndrome, insulin resistance, hyperinsulinemia. 


\section{Вступ}

Для України в останні десятиліття актуальною проблемою залишаються кардіологічні захворювання. Дослідження, які проводили за останні десятиліття, вказують на невпинне зростання поширеності та смертності від хвороб системи кровообігу [1-3]. Провідною патологією в їх структурі залишається артеріальна гіпертензія (АГ), частка якої коливається в межах 40-46\%, а темпи приросту становлять 58,0\% [4-6]. Вона визначає як соціальну, так і економічну складову впливу на здоров'я населення $[5,7]$.

В Україні поширеність АГ становить 29,6\% від усього дорослого населення міської популяції, у сільській місцевості поширеність АГ вища і становить у середньому 36,3\% (для чоловіків та жінок) [8].

Гіперінсулінемія (ГІ) та інсулінорезистентність (IP) сьогодні розглядаються також і як фактор, що асоціюється з АГ. Про тісний зв'язок між IP, АГ та ожирінням ще в 1991 р. наголошували M. Modan та H. Halkin [9]. Таким чином, АГ відіграє важливу роль у серцево-судинному континуумі, є одним із перших клінічних проявів метаболічного синдрому (МC). В основі патогенезу АГ із МC лежить IP, викликана нею компенсаторна ГІ в поєднанні з метаболічними порушеннями [10, 11]. Наявність IP можна визначити за непрямими ознаками - базальна ГІ, індекс Саго, індекс чутливості до інсуліну (ІЧІ), критерії HOMA-IR, індекс IP [12]. При вивченні поширеності IP, визначеної за допомогою методу НОМА (Homeostatic Model Assessment) в італійському популяційному дослідженні, із включенням 888 осіб віком 40-79 років, було встановлено, що її відзначають у 10\% осіб без метаболічних порушень та в $58 \%$ осіб 3 АГ (АТ вищий від 160/95 мм рт. ст.).

Сьогодні жирова тканина - активний ендокринний орган, який виконує низку ендокринних, паракринних та автокринних функцій і в якому синтезується значна кількість гормонів і біологічно активних пептидів [13]. Останніми роками увагу науковців привернула можлива участь жирової тканини, зокрема маркерів ії гормональної активності (лептин, адипонектин, фактор некрозу пухлин альфа (ФНП- $\alpha), \beta_{2}$-рецептори інсуліну), у патогенетичних механізмах формування МС $[14,15]$.

Мета роботи - оцінити активність та кореляційний зв'язок маркерів IP за рівнем лептину, $\beta_{2}$-інсулінових рецепторів, адипоцитокінів, ФНП- $\alpha$ у хворих на АГ із МС залежно від типу інсулінемії.

\section{Матеріал і методи дослідження}

Обстежено 139 хворих на АГ із МС (65 чоловіків, 74 жінки) віком $(68,15 \pm 3,13)$ року. Залежно від рівня ендогенного інсуліну (EI) у крові хворих було розподілено на дві групи. До 1-ї групи з нормальним рівнем ЕІ в крові увійшло 59 хворих, до 2-ї групи зі спонтанною ГІ - 80 хворих на АГ із МС. Контрольну групу становили 20 практично здорових осіб.

Діагноз АГ [16] та МС встановлювали за критеріями The National Cholesterol Education Program (NCEP) [17] на основі наявності будь-яких трьох або більше із таких критеріїв: 1) наявність абдомінального ожиріння за величиною обводу талії (ОТ) >102 см у чоловіків, >88 см у жінок; 2) рівень тригліцеридів у сироватці крові $\geq 1,7$ ммоль/л; 3) рівень АТ $\geq 130 / 85$ мм рт. ст.; 4) рівень ліпопротеїдів високої щільності <1,04 ммоль/л у чоловіків, $<1,29$ ммоль/л у жінок; 5) рівень глюкози в сироватці крові $\geq 6,1$ ммоль/л.

Критеріями виключення із дослідження були наявність тяжких хронічних захворювань легень, нирок, цукровий діабет, інсраркт міокарда менше ніж за 6 місяців до початку дослідження, серцева недостатність ІІБ-ІІІ стадій, ФК III-IV (NYHA), захворювання системи крові, системні захворювання сполучної тканини.

Усім хворим проведено загальноклінічне фізикальне обстеження (скарги, анамнез хвороби та життя, аналіз об'єктивного статусу), визначення антропометричних показників (зріст, маса тіла, От, індекс маси тіла).

Про ступінь IP судили за індексами чутливості до інсуліну (ІЧІ) та Саго — глюкозооксидазним методом, показниками ЕI та $\beta_{2}$-рецепторів інсуліну - імуноферментним методом за допомогою набору Elisa (Німеччина) та показником HOMA-IR за фрормулою:

HOMA-IR = інсулін натще (мкОд/мл) х глюкоза натще (ммоль/л)/22,5.

Наявність системного запалення визначали за рівнем прозапального цитокіну ФНП- $\alpha$, лептину та адипонектину - імуноферментним методом на аналізаторі PR2100 (Sanofi diagnostic Pasteur, France) з використанням наборів фрірми Human Sex-depend test, тести Elisa (Німеччина). 
Статистичну обробку отриманих результатів проводили за допомогою програмного забезпечення - табличного процесора Microsoft Excel та пакета прикладних програм Statistica 10.0 (StatSoft, США). Розраховували основні статистичні параметри: середню арифметичну (М) та її середню похибку ( $\pm m)$, коефіцієнт достовірності (р). Проводили парний факторний кореляційний аналіз з обрахунком коесріцієнта кореляції Пірсона — r.

\section{Результати дослідження та їх обговорення}

Рівень АТ у всіх обстежених хворих коливався в межах $(157,10 \pm 10,07 / 79,20 \pm 5,04)$ мМ рт. Ст.

Встановлено чіткі клінічні, лабораторні та інструментальні характеристики МС у хворих на АГ залежно від рівня ЕІ в крові. Аналіз показників стану IP (табл. 1) показав, що у хворих із нормальним рівнем ЕІ в крові показник ІЧІ відповідав показнику здорових осіб ( $p>0,05)$. При спонтанній ГІ виявився нижчим на 40\% $(p<0,05)$ та $31 \%\left(p_{1}<0,05\right)$ порівняно зі здоровими особами та хворими з нормальним рівнем ЕІ в крові відповідно.

У хворих 1-ї групи індекс Саго натще перебував у межах норми ( $p>0,05)$, у 2-й групі у $3,9(p<0,05)$ і $3,4\left(p_{1}<0,05\right)$ раза був меншим порівняно зі здоровими особами та хворими 1-ї групи відповідно. Показник HOMA-IR натще був достовірно підвищеним у хворих обох груп ( $<<0,05)$. Так, у 1-й групі показник НОМАIR в 1,7 раза перевищував рівень здорових осіб $(p<0,05)$, у 2-й групі - у $6(p<0,05)$ та $2,6\left(p_{1}<0,05\right)$ раза перевищував рівень здорових осіб та хворих 1-ї групи відповідно, що свідчить про вираженість IP при МС і відображає відповідь $\beta$-клітин підшлункової залози на енергетичний стрес.

Рівень ЕІ в крові натще відповідав рівню здорових осіб у хворих із нормальним рівнем EI в крові $(p>0,05)$ і був вищим у 4,7 раза при спонтанній ГІ $(p<0,05)$ та в 3 рази порівняно з хворими 1-ї групи $\left(p_{1}<0,05\right)$.

у 1-й та 2-й групах рівень $\beta_{2}$-рецепторів у 3,4 та 5 разів відповідно перевищував показник у здорових осіб $(p<0,05)$ та виявився в 1,5 раза вищим порівняно із хворими 1-ї групи $\left(p_{1}<0,05\right)$. Отже, підвищення рівня циркулюючих $\beta_{2}$-рецепторів інсуліну у хворих на АГ може свідчити про формування IP у хворих з ожирінням навіть при нормальному рівні циркулюючого ЕІ в крові натще.

Аналізуючи рівні адипоцитокінів (табл. 2), виявили аналогічну закономірність ( $p<0,05$, $\left.\mathrm{p}_{1}<0,05\right)$. У хворих на АГ із МС виявлено гіпоадипонектинемію. У хворих 1-ї та 2-ї груп

\section{Таблиця 1}

Показники інсулінорезистентності у хворих на АГ із МС залежно від рівня ЕІ в крові $(\mathrm{M} \pm \mathrm{m})$

\begin{tabular}{|c|c|c|c|}
\hline \multirow[t]{2}{*}{ Показник } & \multirow{2}{*}{$\begin{array}{l}\text { Здорові особи } \\
(\mathrm{n}=20)\end{array}$} & \multicolumn{2}{|l|}{ Хворі на АГ із МС } \\
\hline & & 1-ша група $(n=59)$ & 2-га група (n=80) \\
\hline \multirow[t]{3}{*}{ ІЧІ натще } & \multirow[t]{3}{*}{$0,015 \pm 0,005$} & $0,019 \pm 0,002$ & $0,006 \pm 0,002$ \\
\hline & & $p>0,05$ & $p<0,05$ \\
\hline & & & $p_{1}>0,05$ \\
\hline \multirow[t]{3}{*}{ Індекс Саго } & \multirow[t]{3}{*}{$0,39 \pm 0,03$} & $0,34 \pm 0,06$ & $0,10 \pm 0,06$ \\
\hline & & $p>0,05$ & $p<0,05$ \\
\hline & & & $p_{1}>0,05$ \\
\hline \multirow[t]{3}{*}{ HOMA-IR } & \multirow[t]{3}{*}{$1,73 \pm 0,26$} & $2,96 \pm 0,62$ & $10,91 \pm 0,60$ \\
\hline & & $p<0,05$ & $p<0,05$ \\
\hline & & & $p_{1}>0,05$ \\
\hline \multirow{3}{*}{$\begin{array}{l}\text { ЕІ в крові, } \\
\text { мкОд/мл }\end{array}$} & \multirow[t]{3}{*}{$10,60 \pm 2,40$} & $15,76 \pm 2,11$ & $49,64 \pm 2,43$ \\
\hline & & $p>0,05$ & $p<0,05$ \\
\hline & & & $p_{1}>0,05$ \\
\hline \multirow{3}{*}{$\begin{array}{l}\beta_{2} \text {-рецепторів } \\
\text { інсуліну, нг/ } \\
\text { мл }\end{array}$} & \multirow[t]{3}{*}{$4,53 \pm 1,63$} & $15,23 \pm 1,51$ & $23,43 \pm 1,03$ \\
\hline & & $p<0,05$ & $p<0,05$ \\
\hline & & & $p_{1}<0,05$ \\
\hline
\end{tabular}

Примітки: $p$ - достовірність різниці порівняно з показниками здорових осіб; $p_{1}$ - достовірність різниці порівняно з показниками хворих 1-ї групи.

\section{Таблиця 2}

Гуморальні показники у хворих на АГ із МС залежно від рівня ЕІ в крові $(\mathrm{M} \pm \mathrm{m})$

\begin{tabular}{|c|c|c|c|}
\hline \multirow[t]{2}{*}{ Показники } & \multirow{2}{*}{$\begin{array}{l}\text { Здорові особи } \\
(\mathrm{n}=20)\end{array}$} & \multicolumn{2}{|c|}{ Хворі на АГ із МС } \\
\hline & & $\begin{array}{l}\text { 1-ша група } \\
(n=59)\end{array}$ & $\begin{array}{l}2-г а \text { група } \\
(n=80)\end{array}$ \\
\hline \multirow[t]{3}{*}{ Лептин, нг/мл } & \multirow[t]{3}{*}{$21,08 \pm 7,48$} & $81,31 \pm 2,23$ & $101,39 \pm 4,06$ \\
\hline & & $p<0,05$ & $p<0,05$ \\
\hline & & & $p_{1}<0,05$ \\
\hline \multirow{3}{*}{$\begin{array}{l}\text { Адипонектин, } \\
\text { мкг/мл }\end{array}$} & \multirow[t]{3}{*}{$1,22 \pm 0,22$} & $1,04 \pm 0,12$ & $0,89 \pm 0,13$ \\
\hline & & $p<0,05$ & $p<0,05$ \\
\hline & & & $p_{1}<0,05$ \\
\hline \multirow[t]{3}{*}{ ФНП- $\alpha$, пг/мл } & \multirow[t]{3}{*}{$21,73 \pm 0,45$} & $24,56 \pm 1,38$ & $29,26 \pm 2,13$ \\
\hline & & $p<0,05$ & $p<0,05$ \\
\hline & & & $\mathrm{p}_{1}<0,05$ \\
\hline
\end{tabular}

Примітки: $p$ - достовірність різниці порівняно з показниками здорових осіб; $p_{1}$ - достовірність різниці порівняно з показниками хворих 1-ї групи. 


\section{Рисунок 1}

Кореляційна залежність між рівнем ЕI та показником $\beta_{2}$-рецепторів інсуліну в крові

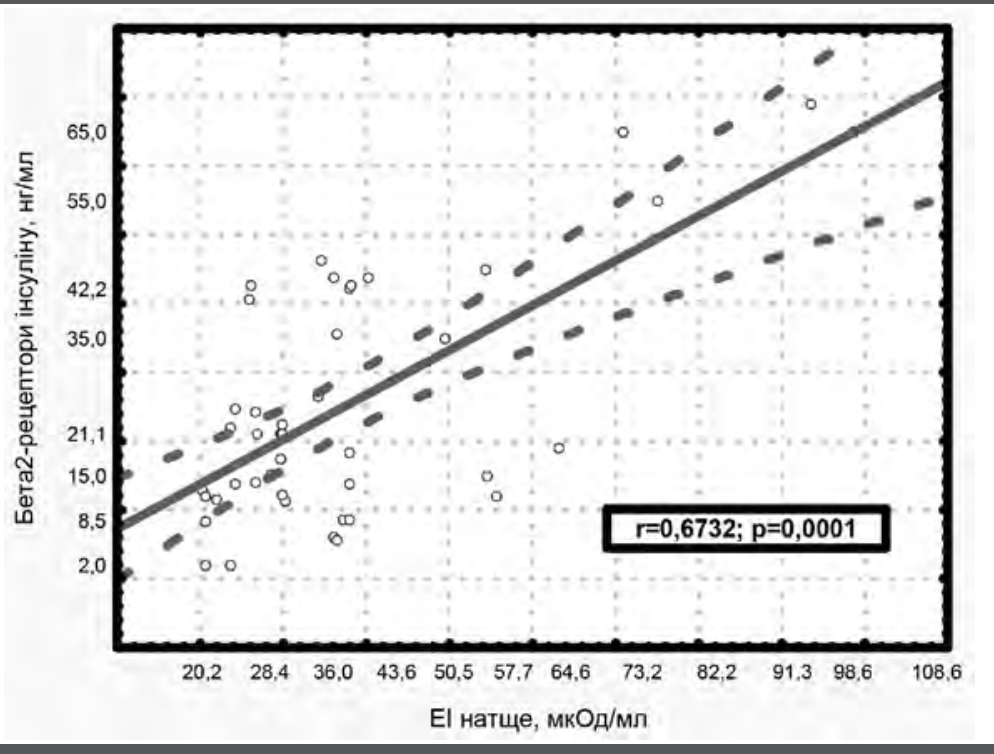

\section{Рисунок 2}

Кореляційна залежність між рівнями ЕІ та лептину

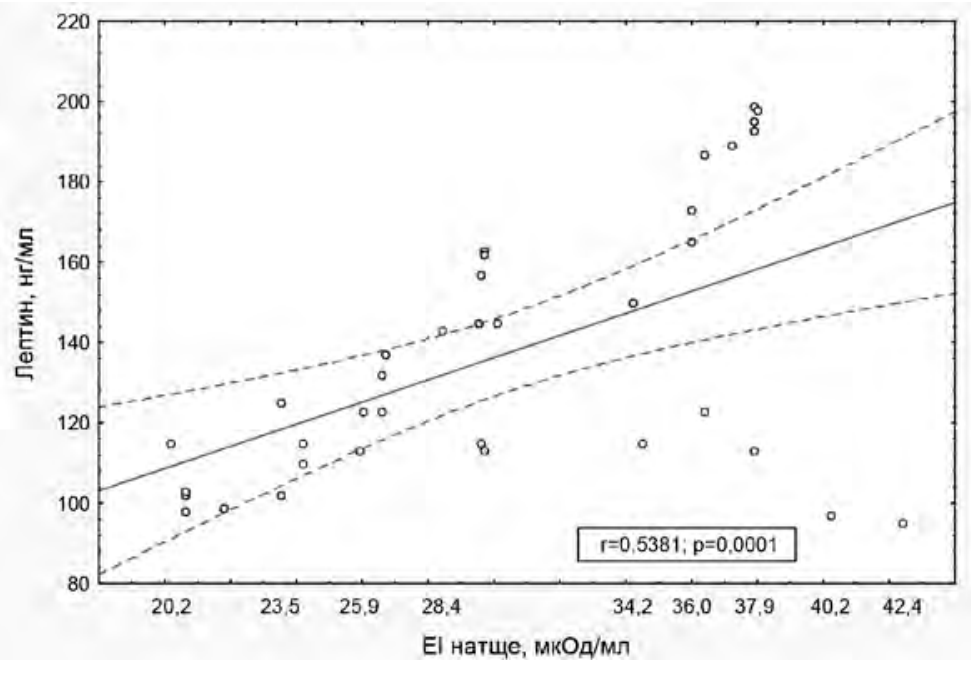

\section{Рисунок 3}

Кореляційна залежність між рівнями ЕI та адипонектину

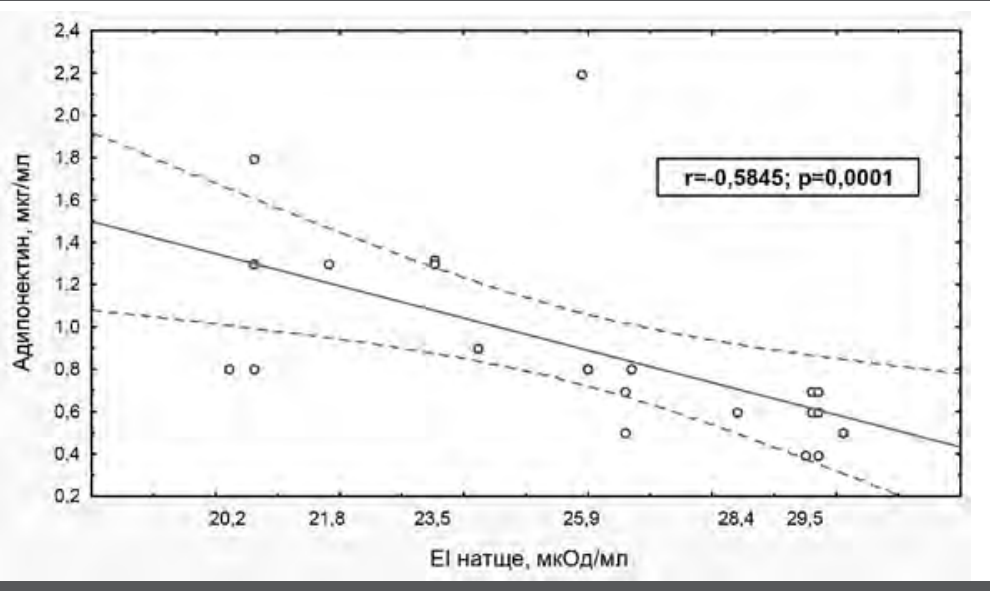

рівень адипонектину виявився зниженим на 14,75 та 27,0\% відповідно порівняно 3 показниками здорових осіб ( $<<0,05)$; у хворих 2-ї групи — на 78\% порівняно з показниками хворих 1-ї групи $\left(\mathrm{p}_{1}<0,05\right)$.

Для всіх обстежених хворих на АГ із МС $є$ характерним достовірне підвищення показників лептину. Так, у хворих 1-ї та 2-ї групи рівень лептину в 3,8 та 4,8 раза відповідно перевищував показник здорових осіб ( $<<0,05)$. У хворих зі спонтанною ГІ рівень лептину був в 1,3 раза вищим порівняно $з$ хворими 3 нормальним El в крові $\left(p_{1}<0,05\right)$.

Оскільки одним з основних компонентів патогенезу АГ і МС є мікрозапалення судин, нами проведено дослідження ключової ланки цитокінового каскаду запальної реакції - визначення рівня ФНП- $\alpha$ залежно від концентрації El в крові. Показник ФНП- $\alpha$ у хворих 1 групи на $13,0 \%, 2$ - на 34,6\% перевищив рівень здорових осіб (р<0,05), та на 19,0\% у хворих зі спонтанною ГІ перевищував показник у пацієнтів з нормальним рівнем ЕІ в крові $\left(p_{1}<0,05\right)$.

Враховуючи, що біла жирова тканина $\epsilon$ важливим ендокринним органом, який пов'язує головний мозок із периферичною тканиною через секрецію цитокінів (ФНП- $\alpha$ ), адипоцитокінів лептину, адипонектину, тому важливою патогенетичною ланкою МС вважається порушення цитокінового профрілю крові.

Аналізуючи показники маркерів ендотеліальної дисфункції, нами проведено визначення кореляційних зв'язків між рівнем ЕІ в крові та рівнем $\beta_{2}$-рецепторів інсуліну (рис. 1), лептином (рис. 2), адипонектином (рис. 3) та ФНП- $\alpha$ (рис. 4) у хворих на АГ із МС.

Нами встановлено наявність прямого кореляційного зв'язку між рівнем EI та $\beta_{2}$-рецепторами інсуліну в крові $(r=0,6732 ; p<0,0001)$.

Аналіз результатів дослідження маркерів ендотеліальної диссрункції довів наявність прямого кореляційного зв'язку між рівнем EI в крові натще та рівнем лептину $(r=0,5381, p=0,0001)$.

Встановлено, що між рівнем адипонектину та показником ЕІ в крові існує зворотний кореляційний зв'язок ( $r=-0,5845, p=0,0001)$.

Виявлено прямий помірний кореляційний зв'язок між рівнем ЕІ в крові натще та ФНП- $\alpha$ $(r=0,47185 ; p<0,05)$.

\section{Висновок}

Для хворих на АГ із МС характерними є інсулінорезистентність та гіперінсулінемія, 
гіперлептинемія та гіпоадипонектинемія, що можуть слугувати маркерами системного запалення.

Гіперлептинемія, зростання рівня ФНП- $\alpha$ та $\beta_{2}$-рецепторів інсуліну в крові призводять до виникнення та прогресування інсулінорезистентності, що дозволяє вважати їх додатковими чинниками несприятливого перебігу МС у хворих на АГ.

Наявність кореляційних взаємозв'язків між рівнем ЕІ в крові натще й маркерами системного запалення: лептином, ФНП- $\alpha, \beta_{2}$-рецепторами інсуліну та адипонектином може свідчити про ступінь вираженості інсулінорезистентності у хворих на АГ із МС.

\section{Рисунок 4}

Кореляційна залежність між рівнями ЕІ та ФНП- $\alpha$ в крові натще у хворих на АГ із МС

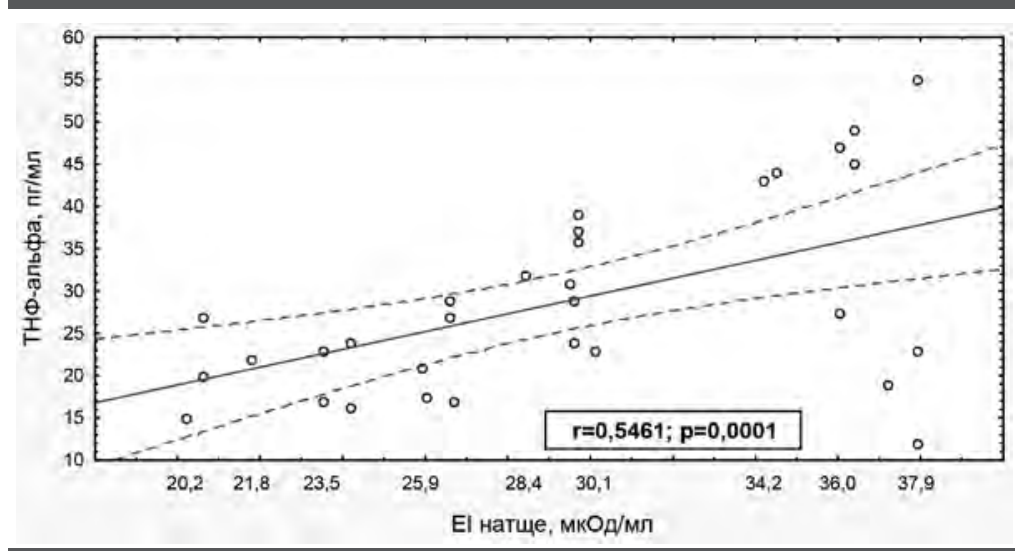

\section{Список використаної літератури}

1. Голяченко ОМ, Шульгай АГ, Голяченко АО. [та ін.] Основні епідеміологічні закономірності хвороб системи кровообігу і гіпертонічної хвороби в Україні. Вісник соціальної гігієни та організації охорони здоров'я України. 2010;4:9-15.

2. Кульчицька ТК. Грузєва ТС, Слабкий ГО. [та ін.] Особливості захворюваності дорослого населення України на хвороби системи кровообігу. Вісник соціальної гігієни та організації охорони здоров'я України. 2001;2:34-38.

3. Теренда НО. Прогностична оцінка захворюваності та поширеності хвороб системи кровообігу. Вісник соціальної гігієни та організації охорони здоров'я України. 2014;4(62):31-35.

4. Білецький СВ, Боднарюк ЛВ, Казанцева ТВ, Бондар Юм. Динаміка захворюваності на хвороби системи кровообігу у жителів міста Чернівці за 1991-2010 рр. Буковинський медичний вісник. 2011;2(15):168-172.

5. Дячук Д.Д. Щодо захворюваності дорослого населення України на неінфекційні хвороби. Вісник соціальної гігієни та організації охорони здоров'я України. 2011;1:19-23.

6. Крапівіна АА. Захворюваність на хвороби системи кровообігу та їх поширеність серед дорослого населення України в 2010 році: гендерний аспект. Здоров'я нації. 2011;4(20):12-18.

7. Іпатов АВ, Сергієні ОВ, Войтчак ТГ, Коваленко ВВ. Сучасний стан первинної інвалідності населення працездатного віку в Україні. Вісник соціальної гігієни та організації охорони здоров'я України. 2006;1:32-37.

8. Теренда НО. Основні тенденції загальної та первинної захворюваності на гіпертонічну хворобу в Україні. Вісник соціальноі гігієни та організації охорони здоров'я України. 2015;4(66):39-43.

9. Modan M, Halkin H. Hyperinsulinemia or increased sympathetic drive as links for obesity and hypertension. Diabetes Care. 1991;14(6):470-487

10. Janus A, Szahidewicz-Krupska E, Mazur G, Doroszko A. Insulin Resistance and Endothelial Dysfunction Constitute a Common Therapeutic Target in Cardiometabolic Disorders. Mediators Inflamm. [Internet]. 2016:3634948. Available from: http://dx.doi. org/10.1155/2016/3634948 DOI: 10.1155/2016/3634948

11. Czech MP. Insulin action and resistance in obesity and type 2 diabetes. Nat Med. 2017 Jul;23(7):804-814.

12. Beverly JK, Budoff MJ. Atherosclerosis: pathophysiology of insulin resistance, hyperglycemia, hyperlipidemia, and inflammation. $J$ Diabetes. 2020 Feb; 12(2):102-104

13. Амбросова ТМ. Метаболічний синдром: адипокінова теорія патогенезу. Актуальні проблеми сучасної медицини. 2013;13(4):215-220

14. Li HJ, Li CP, Zhang C. Association of Adiponectin gene polymorphisms and nonalcoholic fatty liver disease. Int J Clin Experim Med. 2015;16(10):601-609.

15. Mordil, Mordi N, Delles C, Tzemos N. Endothelial dysfunction in human essential hypertension. Journal of Hypertension. 2016 Aug;34(8):1464-72.

16. 2018 ESC/ESH Guidelines for the management of arterial hypertension. European Heart Journal. 2018;39(33):3021-104.

17. Executive Summary of the Third Report of the National Cholesterol Education Program (NCEP) Expert Panel on Detection, Evaluation, and Treatment of High Blood Cholesterol in Adults (Adult Treatment Panel III). JAMA: The Journal of the American Med Association. 2001;285(19):2486-2497. 